\title{
Influence of financial contagion on stock performance of firms listed in the Nairobi securities exchange
}

\author{
Robert Mugo Karungu ${ }^{a^{*}}$, Florence S. Memba ${ }^{b}$ and Willy M. Muturi ${ }^{b}$
}

${ }^{a}$ Department of Accounting, Finance and Management Science, Egerton University Kenya ${ }^{b}$ School Of Business, Jomo Kenyatta University of Agriculture and Technology, Kenya

\section{H R O N I C L E}

\section{Article history:}

Received May 192019

Received in revised format June 232019

Accepted June 292019

Available online

June 292019

Keywords:

Financial Contagion

Nairobi Securities Exchange

Stock Performance

\section{A B S T R A C T}

Financial contagion is the act of spreading of a phenomenon within or from the stock markets sector. Stock markets are highly interlinked and happenings on one side of the world are bound to affect the happenings on another side of the world. The contagion can be because of domestic or international factors. The performance of Nairobi Securities exchange (NSE) was measured by the use of the monthly stock prices as provided by the data vendors at the NSE. This research paper used a quantitative research design where econometric models were used in the analysis. The entire population of the listed firms in the NSE was used. Primary data was collected from the licensed market participants at the NSE. Secondary data during the pre-crisis (April 2006 to July 2007) and post crisis periods (August 2007 to December 2008) were collected using data collection sheets. The data entailed NSE 20 Share Index, FTSE 100 and Standard and Poors and was analyzed using excel and SPSS tools. Hypothesis was tested at 0.05 level of significance and the null hypothesis was rejected at both the primary and the secondary data obtained.

(C) 2020 by the authors; licensee Growing Science, Canada

\section{Introduction}

African stock markets are illiquid and most are characterised by thin trading (Pilinkus, 2010) and this may imply that a security market indicator in Africa may not accurately portray the state of a country's economic performance. During the 2008 global financial crisis, the NSE was hardest hit by the crisis (Ahmed, 2010) yet Kenya is a developing country that is quite distanced from the epicentre of credit crisis in terms of economic growth, industrialization and economic integration (Komo \& Ngugi, 2013). Shen (2011), notes that when distressed traders are subjected to regulatory or leverage constraints, they have to liquidate their positions and this may lead shareholders incurring mark-to-market losses thus being forced to liquidate as well. When a security market indicator is not well composed, there is a risk of financial contagion. Dungey et al.( 2007), observe that if there is a financial contagion, there is continous nervousness, and this can lead to near collapse of an economy.

* Corresponding author.

E-mail address: mugorobert@gmail.com (R. M. Karungu) 
The 2008 global financial meltdown was the worst crisis in history. It started in the developed countries and spread all over the world. In fact a phrase was coined that, 'when United State catches a cold, Europe gets a flu'. Aduda, Oduor and Onwonga (2012), found that that investors experience positive results when they exhibit rationality, but experience negative results when exhibit irrationality and Herding Effect. This study, therefore, aimed at providing insights and adds knowledge in respect to the Influence of securities behavior and the performance of NSE indices. If security indices indicate poor performance, investors, especially debtors would be required to append more cash or securities to get credit facilities (Shen, 2011). Ozkan and Unsal (2012) observe that the global financial crises that took place in the 2000's were triggered by problems in the developed economies that quickly spread to developing economies. A study by Blair et al. (2000), on Standard and Poor's 100 indexes intended to enquire the predictive quality of volatility forecasts from ARCH models. The study notes that the S \& P 100 is the most common index used by American companies. The study also sought to address the importance of selecting a measure of realized volatility in assessing the predictive accuracy of volatility forecasts. A study by Ozkan and Unsal (2012), found that there is lower financial contagion from global financial shock on the domestic economy. The research found that low contagion enables domestic countrys to recover from global financial shocks rapidly on the back of capital flows freeing from foreign towards the domestic economy. It has been established that the majority of contagion in equity markets are sourced through US equity markets while contagion in bond markets is primarily associated with the events in Russia (Dungey \& Gajurel, 2015; Dungey et al., 2007) Financial contagion can be best explained by why the recent 2008 globsl financial crisis have been relatively shortlived for a number of emerging economies (Ozkan \& Unsal, 2012) A collection of literature by Kadilli (2014), observes that stock returns may be predictable because of market inefficiency triggered by investor misperceptions of publicly available information. While this is stated, theory appears to state otherwise information about predictabilility. Sornette (2003), observes that markets are efficient and that only revelation of a dramatic piece of information can cause a crash. However, the author notes that most research is not conclusive as to what this piece of information might be. The collapse of the dot-com bubble in the start of the 21 st Century had severe consequences on the financial markets of US and some Asian countries.

Financial contagion can be divided into three: systematic contagion, idiosyncratic contagion and volatility contagion (Dungey \& Gajure, 2015). The authors establish that stronger capital base, higher market concentration and increased sectorial size can reduce the effect of financial contagion. Systematic contagion is most common with financial markets while idiosyncratic contagion occurs in response to unanticipated sectorial shocks (Dungey \& Gajure, 2015). This may represent the transmission of these shocks in other means apart from portfolio and trading links. There are two cases of financial contagion: fundamental (also known as interdependence between markets) and shift contagion (Hmida, 2014a). Fundamental contagion is the transmission of a shock through real and financial or political channels or after a common shock from the reaction of a rapid decline in global aggregate demand, or remarkable change in exchange rate between major currencies (Hmida, 2014a). In fundamental contagion, transmissions after shock are not significantly different from those before the shock. Shift contagion on the other hand, means propagation shocks from one country to another because of the crucial role played by investor's behaviors and expectations (Hmida, 2014b). In shift contagion, there is a change in transmission mechanisms of shock during or after the crisis and the shock spreads through a channel that did not exist during the stability period. Security market indicators have come to perform a variety of functions: they serve as benchmarks and help answer questions in respect to daily price movements (Fabozzi \& Peterson, 2003). The most commonly quoted security market indicator is the Dow Jones Industrial Average (DJIA) while other security market indicators in the developed countries that are performing excellently include Standards and Poor 500 Composite (S\&P 500), New York Stock Exchange 
Composite Index (NYSE Composite) and the National Association of Securities and Dealers in Automated Quotations (NASDAQ) composite index. In respect to stock markets, the most effective markets worldwide are the American NYSE, German and Netherlands Stock Exchanges (Hájek, 2007). In the world today, there is increased market integration, and this has led to escalated real financial linkage (Islam, 2014). When there is negative co-movement of asset prices, investors get motivated to act, and this motivation comes as a result of the fear of shocks. They react by trying to rebalance their portfolios but since there is information heterogeneity, they experience the contagion effect and volatility spill over. Shen (2011), observes that investors can be able to respond to financial crises in a timely manner if they hold only low degree assets. Financial contagions are spread through direct credit exposure and indirect linkages through holding the same assets and Dungey et al. (2007), observe that large markets act as centres in distributing shocks to periphery markets. A study that looked at financial contagion crisis effect on the Great Seven (G7) economies where the author noted that the Russian crisis, Asian flu and the 2008 Global Financial Crisis were among the most pronounced crisis that have taken place in the past 20 years was conducted by Hmida (2014a). The author concentrates on the 2008 financial crisis, which is the worst financial crisis after the Great Depression of the 1930s. Its outcome was the collapse of mega financial institutions, bail out of banks by national governments and down turns in stock markets worldwide. This crisis staggered all the way to 2012 inform of a persistent global recession where it was estimated that declines in consumer wealth of trillions of US Dollars were lost. Hmida (2014b), observe that there are two cases of contagion: fundamental and shift contagion and through literature, the author establishes that contagion can be measured using correlation co-efficient. Islam (2014), on the other hand, notes that there are two types of contagion: shift contagion and pure contagion. The shift contagion illustrates the propagation of shock beyond normal level in the presence of a crisis period while pure contagion arises due to unexplained fundamentals generally identified in post-crisis periods. In this case, contagion will be present if correlation increases significantly during the crisis period since this will suggest strengthening of links between the markets. The study was based on co-integration theory because it allows study of nonstationery series whose combination is linear and stationery. The hypothesis of the study was that the spread of the crisis between USA and other G7 countries was an act of shift contagion and not an act of fundamental contagion. The researcher tested the hypothesis through two steps: the first being to establish the correlation co-efficients between the stability and crisis periods, and the second by testing the nonlinearity through long term co-integration Influence of the financial markets. In their methodology, daily returns data for USA, UK, France, Germany, Japan, Italy and Canada was used. The study period was divided into two sub-periods: the stability period (from April 10, 2006 to July 31,2007) and period of turmoil and crisis (from August 12007 to December 30, 2008). The author used adjusted correlation test (which measures co-movements between two markets by looking at the correlation co-efficients) and cointegration, linear Error Correlation Methods (ECM) and modelling contagion via nonlinear ECM. In the findings, Hmida (2014a,b), observed that the co-efficient of kurtosis was very high (greater than three) confirming existence of great probability of extreme values. The study also established negative skewness except for USA, France, Germany and Italy. The results indicated that the adjusted correlation co-efficient where the majority of the $\mathrm{Z}$ test results were significant at $0.05 \mathrm{LS}$ ans $0.01 \mathrm{LS}$. This was interpreted as evidence of existence of shift contagion.

A research on behaviour of bank prices and their impact on national security indices was conducted by Komo and Ngugi (2013). Their objectives were: to examine the behaviour of national security market indices across countries at different levels of economic development, to estimate the impact of share prices of leading banks on respective national securities market index, to compare the mean of national stock market idices before (2006-2007) and during (2008-2009) the crisis and to compare the mean and behaviour of bank stock prices across countries at different levels of economic development before (20062007) and during (2008-2009) the credit crisis. The study adopted a multiple regression model and used correlation co-efficient. Among the banks selected in the study were kenyan banks namely Barclays Bank 
of Kenya, Kenya Commercial Bank Ltd, Standard Chartered Bank Ltd, NIC Bank Ltd, and National Bank of Kenya Ltd. In respect to objective one, it was found that six out of nine security market indices were significantly positively correlated with exception of the NSE Index, UK Securities market index and the Brazilian Securities market index. Correlation between the kenyan and the American securities market index was the highest with a coefficient of 0.928 . The findings indicated that all indices were affected by global financial crisis. According to Komo and Ngugi (2013), these findings showed a convergence between the results and existing theories that security market indicators react negatively to news of a failing global market. In the findings, a suprise observation was that the security market indices of Kenya (NSE 20 Share Index) and UK (FTSE 100) had the second highest correlation-that is following the highest correlation coefficient which was between FTSE and NYSE. This contradicts the notion that less developed countries are relatively isolated from capital markets of other countries.

In objective two, in respect to Kenyan banks, it was only two banks out of the five that were found to impact significantly on NSE 20 share index at 95\% confidence level: these were NIC and Standard Chartered Bank where NIC affected the index negatively while Standard Chartered Bank affected the index positively. The adjusted $\mathrm{r}^{2}$ explained the variations to the extent of $87 \%$. On objective three, a paired sample $\mathrm{Z}$ test was carried out to test the mean differences before and during the credit crisis. The results indicated that all the indices studied had a statistically significant mean difference. The results also indicated that all countries except Brazil and India had statistically significant negative correlations. This, according to Komo and Ngugi (2013), could probably indicate that the crisis spread at different times across different countries or some countries were hard hit than others. The findings were that the correlation for indices before and after crisis was noZ statistically significant for the countries in the emerging countries. The results of paired sample correlation analysis of security market indices and mean bank share prices before and during the crisis showed that those indices that were statistically significant were negatively correlated. NSE had the highest correlation (-0.909) indicating that before the crisis, the prices moved in one direction and during the crisis they moved in opposite direction. A study on a paper titled Fama on Bubbles, where he was looking at the rational bubbles on stock returns predictability. The researcher called for Fama's views on rational bubbles and discussed whether such bubbles are inconsistent with Fama's empirical findings on returns predictability. Rational bubbles are determined by the fundamental value of a firm. Islam (2014), observes that when there is financial contagion, risks that are idiosyncratic in nature (country based) fuels the transmission of shocks through non contigent channels into countries of different peripheries with minimal or no financial linkage. The author observes that it is through small but highly correlated risk factors that the overall risk is compounded during crisis periods. A working paper by Ozkan and Unsal (2012), on Global Financial Crisis, Financial Contagion and Emerging Markets and found that a small economy facing a sudden stop of capital inflows due to financial distress in a developed country is likely to suffer a more prolonged crisis than the origin country of the crisis. This is because the country with the small economy may be unable to get out of the crisis due to slump in its consumer demand. Contrary to theory, the authors also found that if a financial shock originates domestically, the host country may be able to recover because the direct effect will be the depreciation of its currency which will result in a current account reversal. Dungey and Gajure (2014), did a research on contagion and banking crisis during the 2007-2009 crisis fro 50 countries. Through collection of literature, the authors observe that banking crises transmitted from other jurisdictions present a higher risk than that provided by currency or debt crises. The results establish that systematic contagion may not significantly increase the chances of a crisis arising out of a crisis elsewhere if there have already been current policy responses being implemented. The authors found that banking sector is strongly related through idiosyncratic contangion which represents the unanticipated impact of shocks affecting the crisis originating asset. Systemic contagion is the transmission of common shocks which may hit a global or regional market and they originate from the same source. It was observed that the Russian and Long Term Capital Management 
Crises (LTCM) originated in bond markets but were rapidly transmitted through international equity markets (Dungey et al., 2007). In 1998, there was great nervousness in the Russian banking and financial sectors which resulted to the suspension of payment of Russia's sovereign bond and floating of the Russian currency in August 1998. Russian crisis were soon followed by the near default of the US hedge fund LTCM and these shocks had far reaching effects on the global markets. The primary shocks began in bond markets but their repercussions were felt in the financial markets and high volatility in the international bond markets. The above authors uses the factor model to identify the transmission mechanisms of financial crises where the model identifies financial contagion during crises periods. The authors did a research on six emerging equity markets (Argentina, Brazil, Hong Kong, Thailand, Poland and Russia) and four industrial equity markets (Germany, Japan, United Kingdom and United States). The returns of the 10 countries were represented by Vector Autoregression (VAR) where equity returns of a country $i$ at time $t$ would be obtained from the sum of various variables. These variables are mean vector of parameters that allowed for non-zero means in equity returns, matrix for autoregressive parameters that would correspond the $i$ th lag, and multivariate disturbance process with zero mean, variance, and variance-covariance matrix which would represent shock to equity markets which are assumed to have been derived from a set of factors. The authors note that the length of the lag distribution of Vector Autoregressive is given by $p$ and they analyse two factors that distinguish the emerging markets and the developed markets. One factor captures the specific shocks in the emerging markets and is the size is controlled by Gamma factor while the other factor captures the shocks in the four industrial developed equity markets with the size controlled by the Delta factor.

A benchmark period to begin on January 51998 and end on July 31 1998. The Russian crisis began on August 3 and ended on August 31 was selected by Dungey et al.(2007). The Long Term Capital Management (LTCM) crises was chosen to run from August 31 to October 15. From the findings, it was observed that the parameter estimates of the common factor showed that all equity markets react in the same direction to world shocks with the effect tending to be larger in emerging markets than in industrial developed markets: infact the latin American Stock Markets experienced more than double the shock impacts received by the US and the only slight difference was the Japanese Market. The findings on the contagion parameter estimates showed that countries such as Germany and the UK react negatively to the Russian crises with positive results between the Russian crises and the emerging markets which were all statistically insignificant. In contrast to the Russian crises, Dungey et al.(2007), observed that the effects of contagion of the LTCM crises were all statistically significant. Their conclusions were that contagion was found to be the highest in the industrial markets and especially latin American markets that were geographically close to the US. The authors suggested that future researchers should combine both bonds and equities to test the importance of contagious transmission mechanisms across international borders. They also propose development of a multiple regime model that will allow for multiple crises.

\section{Materials and Methods}

For international security market indicators the researcher will collect data from Standard and Poor's 500 (S\&P 500) of the New York Stock Exchange (NYSE) and from the Financial Times Stock Exchange (FTSE) Index of the London Stock Exchange (LSE) and this data helped address the variable of financial contagion. The data of interest to the researcher was specifically be the monthly share prices of the companies listed in the exchange, and the price movements were computed to obtain monthly stock returns. A point to note is that in monthly prices, the data vendors at NSE normally provide the prices of the last trading day of the month under consideration. A linear time series regression model based on OLS criteria was adopted for each objective and the data analysis tool that was used will be the Statistical Package for Social Scientists (SPSS) version 21. The monthly returns were then be input on each model and basing on the formulas given, analysis was done on each variable. The hypothesis, which tested how the Kenyan 
securities markets react to financial contagion was be measured by collection of monthly prices $\left(P_{i, t}\right)$ of the firms listed at the Nairobi Securities Exchange compared to other prices from deveoloped stock markets for the period in which the crisis occured. This was presented by moving averages and adjusted correlation tests. Data analysed helped to capture major global events like the 2008 global crises which affected the financial markets for the whole world. The study used data for year before the crisis and the years after the crisis. The study period before the crisis was between April 102006 and July 31 2007, while the period during the crisis was between August 12007 and 30 December 2008 (Hmida, 2014a), where it compared how the security market indicators in the developed countries and those in the Kenyan securities market reacted to global financial meltdown. The researcher used data from New York Stock Exchange (NYSE) and that from London Stock Exchange (LSE) since these are the leading stock markets in the world and the global financial crises struck first in these stock markets. This is in line withDungey et. al (2007), who note that it would be important to factor several regimes when deciding whether to extend the period. Monthly percentage equity returns at time $t$ would be computed as:

$S_{i t}=100\left(\ln \left(P_{i, t}\right)-\left(\ell n\left(P_{i, t-1}\right)\right)\right.$

where:

$S_{i t}$ is the equity returns of a country at time $t$ while 100 is the base year index

$\ell n$ is the natural logarithm factor

$P_{i, t}$ is the price of security $i$ at time $t$

In the above model, missing observations can be filled by use of a linear interpolation between observed prices for this doesnot change the qualitative results of the estimated factor model. A moving average was chosen to capture differences in time zones of the NSE indices with those of developed countries. In addition to moving averages, financial contagion was also determined by the use of adjusted correlation test. This has been used in the research by Hmida (2014b), who looked at financial contagion effect of subprime crisis on the G 7 countries. In this test, co-movements between two markets are measured by their correlation co-efficients. Increase in correlation co-efficients may be biased by the effect of the changes in variability of the market originated shock which causes heteroskedasticity problem. To correct the bias, a simple linear model can be used as follows:

$Y_{t}=\alpha+\beta X_{t}+\varepsilon_{t}$

where $Y_{t}$ and $X_{t}$ are two financial series identifying returns of assets in two different markets.

$\alpha$ is the alpha value and $\varepsilon_{t}$ is the error term

Expected Error term $\left(E\left(\varepsilon_{t}\right)\right)=0$ and $E\left(\varepsilon_{t}\right)<\infty$

Correlation co-efficient $\left(P\left(x_{t} y_{t}\right)\right)$ will be obtained by:

$P\left(x_{t} y_{t}=\frac{\operatorname{cov}\left(x_{t} y_{t}\right)}{\sigma x_{t} \sigma y_{t}}\right.$

where $\operatorname{cov}\left(x_{t} y_{t}\right)$ is the covariance between market $\mathrm{x}$ and $\mathrm{y}, \sigma x_{t}$ is the standard deviation of market $\mathrm{x}$ and $\sigma y_{t}$ is the standard deviation of market y. The adjusted co-efficient will be $P^{*}$ which is

$P^{*}=\frac{P}{\sqrt{1+\delta\left(1-(P)^{2}\right)}}$

where $\delta$ is known as delta, which is the relative increase of the variance of $\mathrm{x}$ between the periods of crisis and stability

$\delta=\frac{V^{c}\left(x_{t}\right)}{V^{t}\left(x_{t}\right)}-1 \mathrm{c}$ and $\mathrm{t}$ indicate the periods of crisis and tranquility. 
The adjusted correlation co-efficient for each pair of countries in th sample will then be tested statistically to establish whether or not it is shift contagion, where:

$P_{1}^{*}$ will be the adjusted correlation co-efficient during crisis period and $P_{2}^{*}$ will be the adjusted correlation co-efficient during the stable period. A $Z$ test will be used to test for the significance of the findings. Hmida (2014a), observes that if the null hypothesis is rejected, the correlation co-efficient between the two countries has significantly increased between the stability period and the crisis period, it is evidence of shift contagion. On the otherhand, if null hypothesis is not rejected, it is evidence of fundamental contagion between the two markets. Thus in the analysis, the researcher will establish each type of contagion that will be witnessed in the findings.

\section{Results}

From the analysis, it was found that there was no collinearity between financial contagion and NSE 20 Share Index. The Eigen Values observed on FTSE 100, Standard and Poors, and NSE 20 Share Index were all less than 10. This is shown on Table 4.1

Table 1

Collinearity Diagnostics on the Influence of Financial Contagion and Performance of NSE 20 Share Index

\begin{tabular}{lllllll}
\hline Model & Dimension & Eigenvalue & Condition Index & \multicolumn{3}{l}{ Variance Proportions } \\
\cline { 5 - 6 } & & & & (Constant) & FTSE 100 & STD \& POORS \\
\hline & 1 & 2.980 & 1.000 & .00 & .00 & .00 \\
& 2 & .018 & 13.034 & .00 & .23 & .36 \\
& 3 & .002 & 35.398 & 1.00 & .77 & .64 \\
\hline
\end{tabular}

a. Dependent Variable: NSE 20

Descriptive statistics on the Influence of financial contagion and performance of the NSE indices were also established. Fig. 1 captures the objective of financial contagion between NSE 20 Share index and the FTSE 100 index during the pre-crisis period. This period happened to fall between April 2006 to July 2007. There is high interconnection between these indices as portrayed by the figure below. FTSE 100 started at around 8900 points, reduced slightly, and then increased gradually to around 10300 points while NSE 20 Share index started at around 3000 points in April 2006, reduced slightly and rose gradually to around 4100 points in July 2007. This agrees with the observations made by Komo \& Ngugi (2013) who agreed that NSE is highly interlinked with the UK stock market despite NSE being an emerging market and also geographically very far from the European Country.

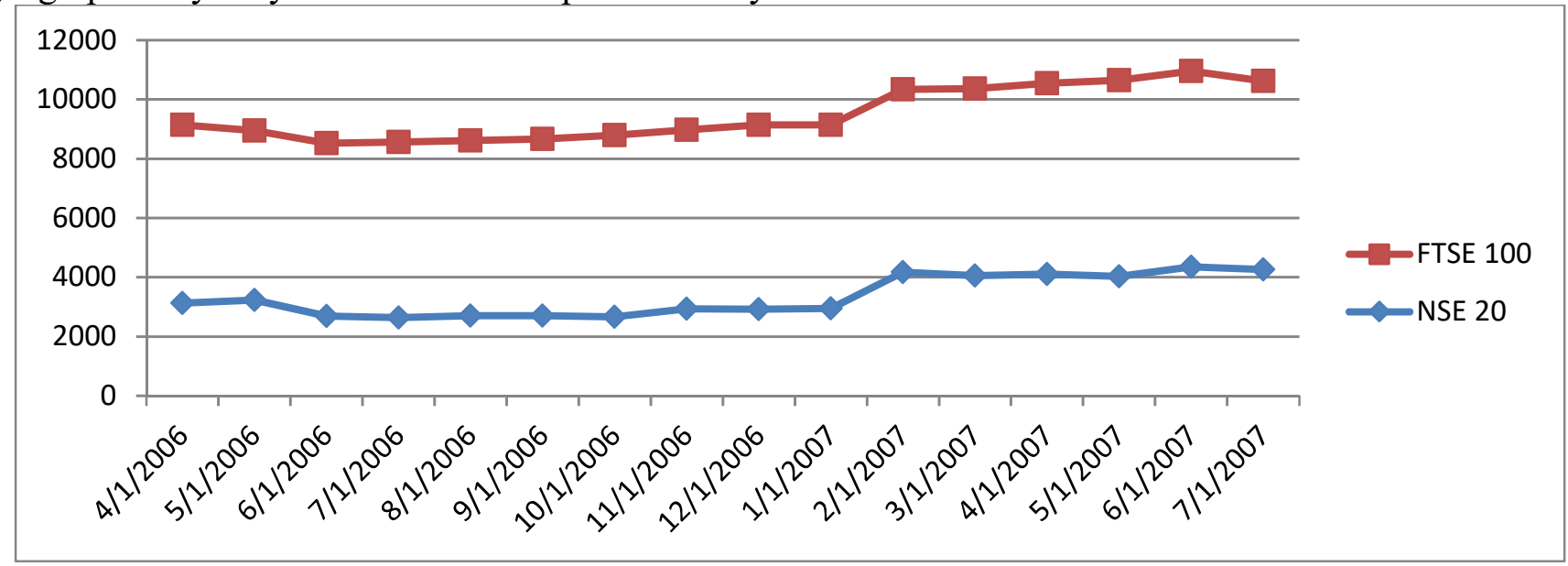

Fig. 1. Influence of NSE 20 Share Index on FTSE 100 Index during the Pre-Crisis Period 
Fig. 2 shows the Influence of the Standard and Poor's 500 and the NSE 20 share index during the pre-crisis period. The NSE 20 share index started at around 3050 points in April 2006 and closed at 4100 points in July 2007 while the Standard and poor's changed from around 4500 points to around 5800 points in the same period respectively. Just like the Fig. 2 above the outcome of this figure also confirms the works of (Komo \& Ngugi, 2013) that NSE is highly interlinked with other exchanges all over the world.

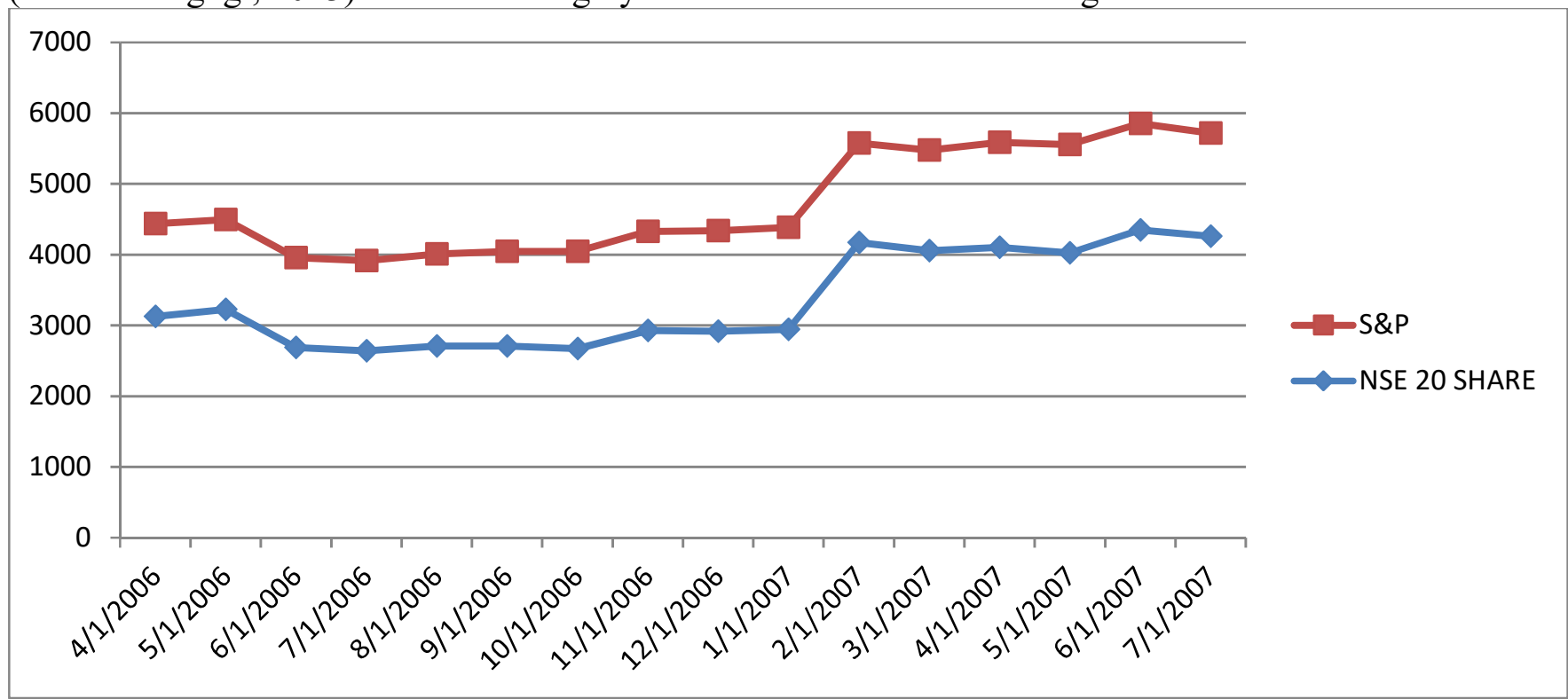

Fig. 2. Influence of NSE 20 Share Index on Standard and Poor's During the Pre-Crisis Period

The post crisis period (August 2007 to December 2008) was also studied and is presented in figures 4.3 and 4.4 as shown below. Figure $4.3(\mathrm{~m})$ below shows that NSE 20 Share Index lost from 7000 points in August 2007 to just above 4000 points in December 2008 while the FTSE 100 Index lost from 1500 points to slightly below 1000 points. The above observations were in disagreement with the research by Komo and Ngugi, (2013) who stated that there is high correlation between the UK and the Kenyan securities markets. However, it is worth noting that despite the reduction at different rates, all the indices under observation all fell during the post 2008 financial crisis period.

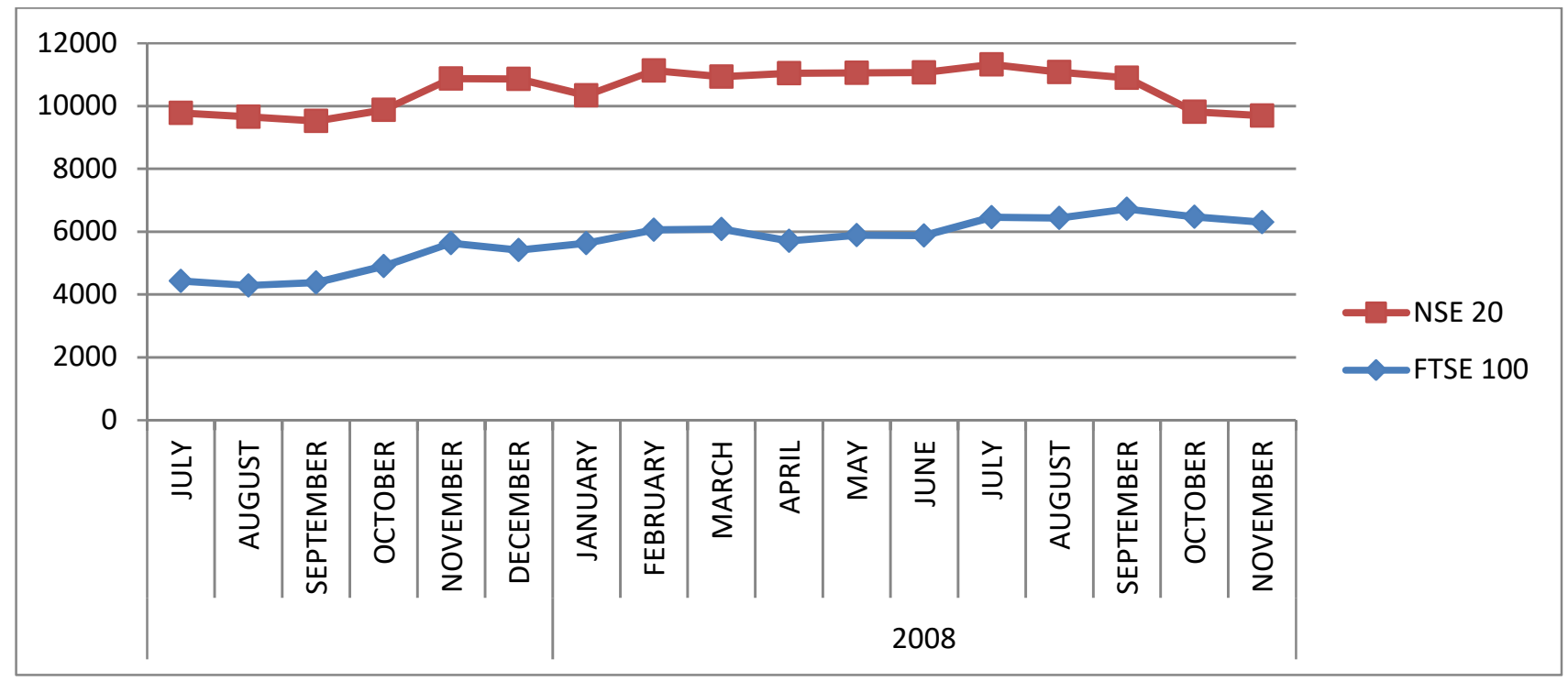

Fig. 3. Post crisis Influence of the NSE 20 Share Index on FTSE 100 Index 
In respect to the Influence of NSE 20 Share Index and Standard and poor's during the post crisis period, the NSE 20 Share Index lost from just below 7000 points in August 2007 to just above 4000 points in December 2008 while the Standard and Poor's lost from around 5200 points to around 3500 points in the same periods respectively. This is quite in agreement with the works of Komo and Ngugi (2013) who noted that the NSE is highly interconnected with the global events despite being an emerging market and geographically separated frontier.

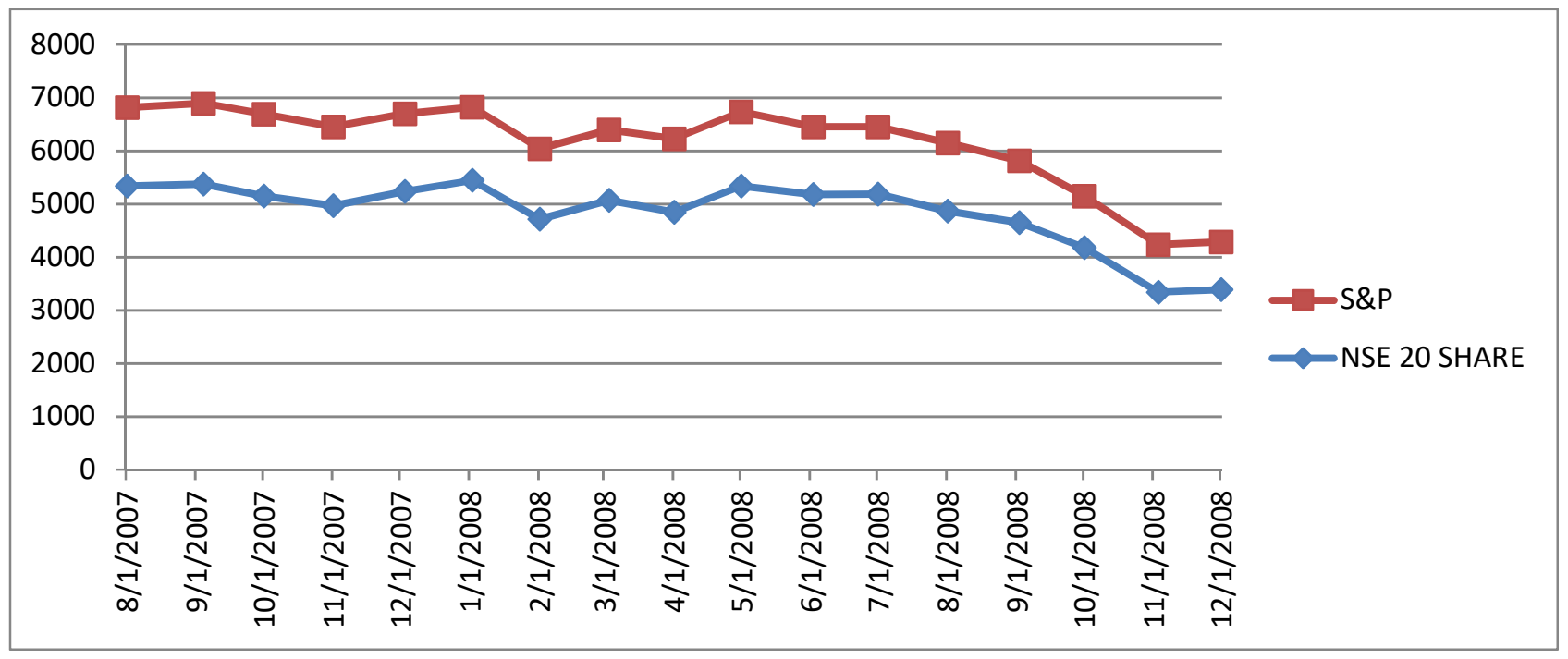

Fig. 4. Post Crisis Influence Of The NSE 20 Share Index on Standard \& Poor's Index After conducting pre and post crisis periods separately, the researcher also found it necessary to combine the two and establish their effects. The periods starting from April 2006 to June 2007, and August 2006 to October 2008 were conducted for both NSE 20 Share Index and FTSE 100, and NSE 20 Share Index and Standard and poor's Index. Fig. 5 below captures the pre and post crisis Influence of NSE 20 Share Index and the FTSE 100 Index. As captured in the above figures, for the pre-crisis period, the two indices were moving in the same direction, but this cannot be stated for the post crisis periods.

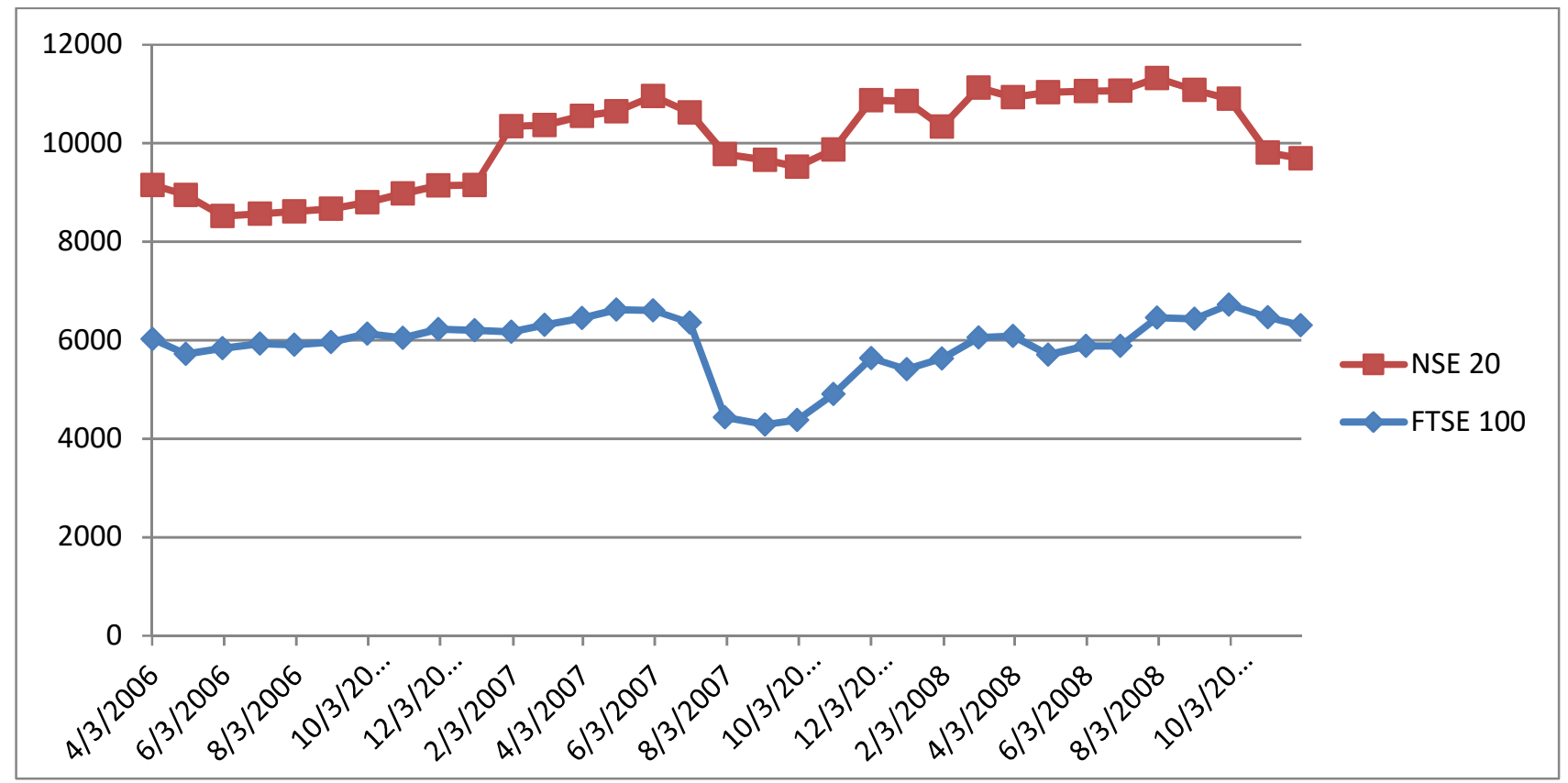

Fig. 6. Pre and post crisis Influence of the performance of NSE 20 Share Index on FTSE 100 
The pre and post crisis Influence of the NSE 20 Share Index and Standard and Poor's Index was also established. This is shown on Fig. 6.

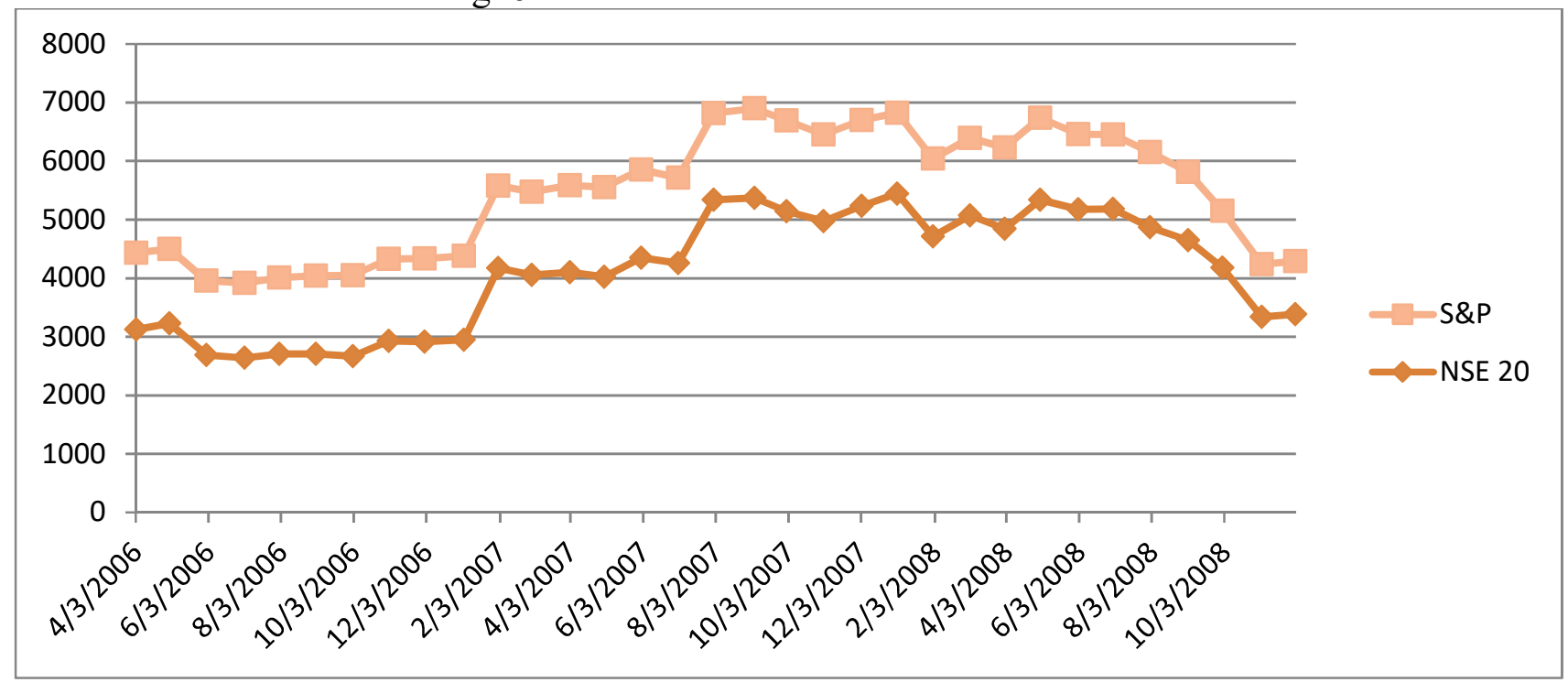

Fig. 6. Pre and post crisis Influence of the performance of NSE 20 Share Index on Standard and poor's Index

To cap the discussion was a line chart that captured the three indices studied in respect to the pre and post crisis indices movement. This was captured by figure 4.7. The figure shows that NSE is not highly contagious of the happenings of the outside developed countries and this in itself disagrees with the works of Komo and Ngugi (2013).

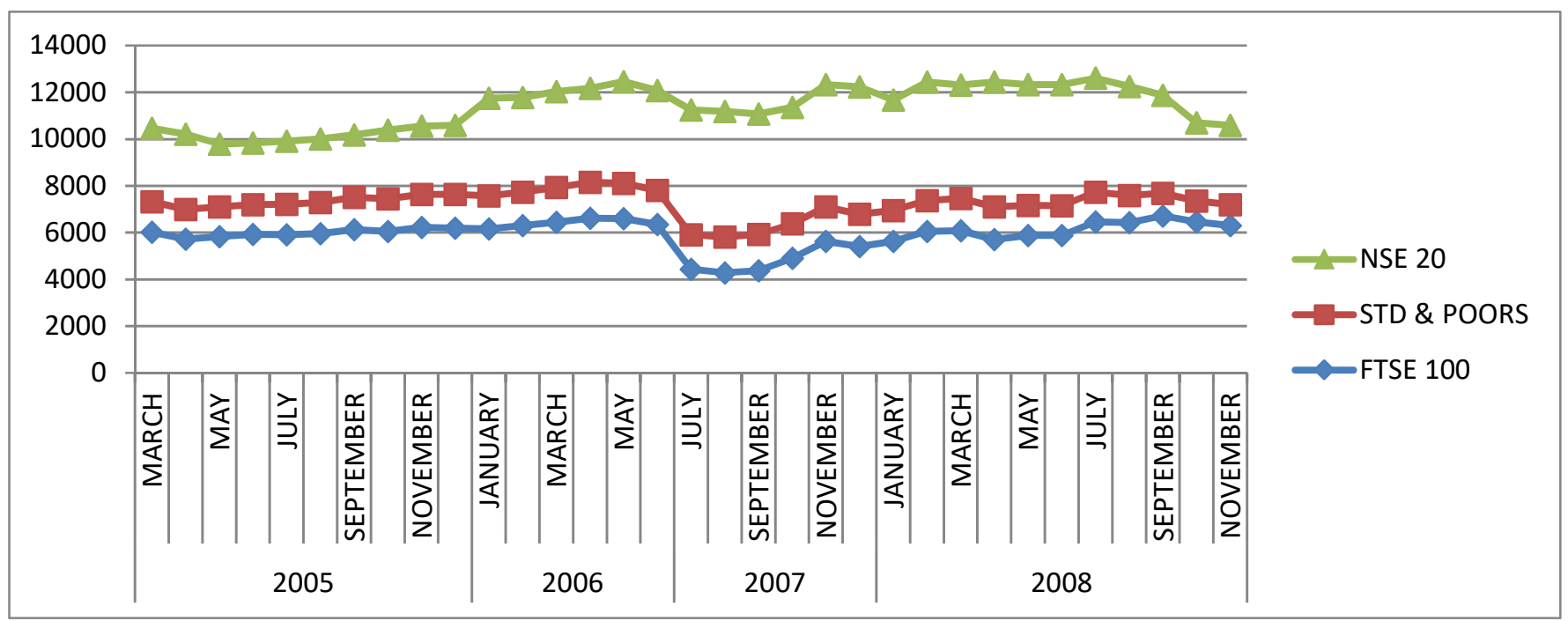

Fig. 7. Pre and Post Crisis Influence of the Performance of NSE 20 Share Index on Standard \& Poor Index

Table 2

Descriptive Statistics on the Relationship Amongst NSE 20 Share Index, FTSE 100 and Standard \& Poor's During the Pre and Post Crisis Period

\begin{tabular}{llll}
\hline & Mean & Std. Deviation & $\mathrm{N}$ \\
\hline NSE 20 & 4114.8255 & 996.30420 & 33 \\
FTSE 100 & 5913.945 & 622.1936 & 33 \\
STD \& POOR'S & 1341.9370 & 163.24456 & 33 \\
\hline
\end{tabular}


The relationship amongst the three variables was established. The overall mean of NSE 20 share index was 4114.83 points with a standard deviation of 996.30, while that of FTSE 100 was 5913.95 points with a standard deviation of 622.2, and that of Standard \& Poors was 1341.94 points with a standard deviation of 163. This was for the pre-crisis and post crisis period. This has been captured by Table 2 . From the above table, it can be concluded that NSE 20 share index was the most volatile during the global financial crisis period. This disagrees with the work of Komo \& Ngugi, (2013) who found that the Nairobi Securities Exchange is highly correlated with the developed markets but agrees with the work of Hmida (2014a) who noted that the happenings of the developed world adversely affect the developing countries. On this analysis, data was split into pre crisis period, post crisis period and a combination of the pre and post crisis period. Table 3 captures the pre-crisis Influence of FTSE 100 and NSE 20 Share index. From the table, the correlation between these two indices stood at 0.763 . this is in agreement with the works of Komo and Ngugi (2013) who observed that there is a high correlation between the NSE and the developed stock markets despite the fact that the two are geographically and economically very distinct. This also affirms the Fig. 7 which captured diagrammatically this relationship. The $\mathrm{z}$ statistical was at -14.532 , $\mathrm{z}$ critical at 2.1 and $P$ value at 2.118893E-11.

\section{Table 3}

Pre Crisis Influence of FTSE 100 on NSE 20 Share Index

\begin{tabular}{lll}
\hline$Z$ test: Two-Sample Assuming Unequal Variances & & \\
\hline & & 6023.1 \\
Mean & 3126.04 & 6164.84 \\
Variance & 3360.216667 & 73755.21543 \\
Observations & 484981.8756 & 15 \\
Pearson Correlation & 15 & \\
$Z$ s stat & 0.763160061 & \\
$P(T<=t)$ one-tail & -14.43169992 \\
$Z$ Critical one-tail & $1.09446 \mathrm{E}-11$ \\
$\mathrm{P}(\mathrm{T}<=\mathrm{t})$ two-tail & 1.734063607 & \\
$\mathrm{Z}$ Critical two-tail & $2.18893 \mathrm{E}-11$ & \\
\hline
\end{tabular}

The above observations showed that the Influence of FTSE 100 and NSE 20 Share Index was statistically significant at 0.05 Level of significance. This was also confirmed by the P value which was lower than 0.05. Table 4 captures the Influence of the Standard \& Poors Index and the performance of NSE 20 Share Index. There were a total of 15 observations with $\mathrm{z}$ statistical of $10.86, \mathrm{Z}$ critical of 2.144 an $\mathrm{P}$ value of $3.328 \mathrm{E}-12$. These observations showed that the statistical value of $\mathrm{z}$ was inside the critical region.

\section{Table 4}

Pre Crisis Influence of Standard and Poor's on NSE 20 Share Index

\begin{tabular}{lll}
\hline z-Test: Two-Sample Assuming Unequal Variances & \\
Mean & 1310.61 & 3126.04 \\
Variance & 1392.734667 & 3360.216667 \\
Observations & 7275.694241 & 484981.8756 \\
Z Stat & 15 & 15 \\
$\mathrm{P}(\mathrm{T}<=\mathrm{z})$ one-tail & & 10.86075947 \\
$\mathrm{z}$ Critical one-tail & & $1.66407 \mathrm{E}-08$ \\
$\mathrm{P}(\mathrm{T}<=\mathrm{z})$ two-tail & & 1.761310136 \\
$\mathrm{z}$ Critical two-tail & & $3.32813 \mathrm{E}-08$ \\
\hline
\end{tabular}

The above observations showed that the Influence of Standard and Poor's and NSE 20 Share Index was statistically significant at 0.05 Level of significance. This was also confirmed by the $\mathrm{P}$ value which was lower than 0.05. Post crisis period started from July 2007 to November 2008. The researcher studied the 
post crisis period Influence of FTSE 100 and NSE 20 Share index, Standard and Poor's Index and NSE 20 Share Index. These are captured on Tables 4.5 and 4.6. On the Influence of Standard \& Poors and NSE 20 share index as shown on Table 5 the correlation between the two indices was 0.847 implying that it was a strong positive correlation between Standard \& Poors and NSE 20 Share index. This is in agreement with the research of Komo and Ngugi (2013), who found that there was a strong correlation between Kenyan Securities Markets and developed markets in the world. Z statistical was 20.72016097 , z critical was 2.10092204, and the P value was 5.22553E-14.

\section{Table 5}

Post Crisis Influence of Standard and Poor's on NSE 20 Share Index Z-Test: Two-Sample Assuming Unequal Variances

\begin{tabular}{lll}
\hline & & 1473.99 \\
\hline Mean & 5340.08 & 1288.01875 \\
Variance & 4807.491875 & 43150.7442 \\
Observations & 418473.9567 & 16 \\
Pearson Correlation & 16 & 0.84753574 \\
Z Stat & 20.72016097 & \\
$\mathrm{P}(\mathrm{T}<=\mathrm{t})$ one-tail & $2.61277 \mathrm{E}-14$ \\
$\mathrm{Z} \mathrm{Critical} \mathrm{one-tail}$ & 1.734063607 & \\
$\mathrm{P}(\mathrm{T}<=\mathrm{t})$ two-tail & $5.22553 \mathrm{E}-14$ \\
$\mathrm{Z}$ Critical two-tail & 2.10092204 \\
\hline
\end{tabular}

The above results imply that since the $\mathrm{P}$ value is less than 0.05 and that the $\mathrm{Z}$ statistical is greater than $\mathrm{Z}$ critical, the post crisis Influence of Standard \& Poors and the NSE 20 Share Index was statistically significant at 0.05 level of significance. Table 6 shows the post crisis Influence of FTSE 100 and NSE 20 Share Index. The correlation between the two indices stood at $-0.57, \mathrm{Z}$ statistical was $3.94383631, \mathrm{Z}$ critical was 2.042272456 and the $\mathrm{P}$ value was 0.000445474 . $Z$ statistical was inside the critical region since it was greater than $\mathrm{Z}$ statistical.

\section{Table 6}

Post Crisis Influence of FTSE 100 on NSE 20 Share Index

Z-Test: Two-Sample Assuming Unequal Variances

\begin{tabular}{lll}
\hline & & 5340.08 \\
\hline Mean & 4434.2 & 4807.491875 \\
Variance & 5764.39375 & 418473.9567 \\
Observations & 523452.578 & 16 \\
Pearson Correlation & 16 & \\
$Z$ Stat & -0.573601547 & \\
$\mathrm{P}(\mathrm{T}<=\mathrm{t})$ one-tail & 3.94383631 & \\
$\mathrm{Z}$ Critical one-tail & 0.000222737 & \\
$\mathrm{P}(\mathrm{T}<=\mathrm{t})$ two-tail & 1.697260887 & \\
$Z$ Critical two-tail & 0.000445474 & \\
\hline
\end{tabular}

A negative correlation in the above table implies that the FTSE 100 and NSE 20 Share Index were moving in opposite directions after the 2008 crisis. This goes against the findings of Komo and Ngugi (2013) who had observed that the NSE is highly interlinked with the developments of the developed economies making it highly contagious in its price movements. The post crisis Influence of the FTSE 100 and the NSE 20 Share Index was statistically significant at 0.05 level of significance since $Z$ statistical was greater than $Z$ critical. This was also confirmed by the $\mathrm{P}$ value which was less than 0.05 . The final aspect of inferential statistics on the pre and post crisis Influence of financial contagion and the performance of NSE indices was conducted. The researcher first established the Influence of each variable and NSE indices, and then 
conducted a combined Influence of Standard and poor's, and FTSE 100 indices and NSE 20 Share index where the latter would be the dependent variable. Table 7 shows the pre and post crisis Influence of the FTSE 100 and NSE 20 Share Index. The correlation between the two variables stood at $-0.4261121, \mathrm{z}$ statistical was 8.463637222 , $\mathrm{z}$ critical was 2.006646805 and the $\mathrm{P}$ value was $2.37289 \mathrm{E}-11$.

\section{Table 7}

Post Crisis Influence of FTSE 100 on NSE 20 Share Index

Z-Test: Two-Sample Assuming Unequal Variances

\begin{tabular}{lll}
\hline & & \\
\hline Mean & 6023.1 & 3126.04 \\
Variance & 5910.534375 & 4145.725 \\
Observations & 399216.4017 & 992117.9339 \\
Pearson Correlation & 32 & 32 \\
$Z$ Stat & -0.4261121 & \\
$\mathrm{P}(\mathrm{T}<=\mathrm{t})$ one-tail & 8.463637222 & \\
$\mathrm{Z}$ Critical one-tail & $1.18645 \mathrm{E}-11$ & \\
$\mathrm{P}(\mathrm{T}<=\mathrm{t})$ two-tail & 1.674689154 & \\
$\mathrm{Z}$ Critical two-tail & $2.37289 \mathrm{E}-11$ & \\
\hline
\end{tabular}

From the above table, one would draw that there existed a negative correlation between FTSE 100 index and NSE 20 Share index. This statement is not in agreement with the works of Komo and Ngugi (2013) who found that NSE is highly contagious on the happenings of the developed world. This statement thus refutes the statement that 'When America catches a cold, the world gets a flu'. Z statistical was in the critical region since it was greater than $\mathrm{Z}$ critical. This would make one to conclude that the pre and post crisis Influence of FTSE 100 and NSE 20 Share index was statistically significant at 95\% confidence level. This was confirmed by the $\mathrm{P}$ value being less than 0.05 . Table 8 captures the pre and post crisis Influence of Standard and poor's index and NSE 20 Share Index. The correlation between these two variables stood at 0.27 , $\mathrm{z}$ statistical was 15.70199838, $\mathrm{z}$ critical was 2.034515297 and $\mathrm{P}$ value was 7.14253E-17.

\section{Table 8}

Post Crisis Influence of Standard and Poor's on NSE 20 Share Index

Z-Test: Two-Sample Assuming Unequal Variances

\begin{tabular}{lll}
\hline & 3126.04 & 1310.61 \\
\hline Mean & 4145.725 & 1342.915938 \\
Oariance & 992117.9339 & 27475.77735 \\
Pearson Correlation & 32 & 32 \\
$Z$ Stat & 0.270427572 & \\
$\mathrm{P}(\mathrm{T}<=\mathrm{t})$ one-tail & 15.70199838 & \\
$\mathrm{Z} \mathrm{Critical} \mathrm{one-tail}$ & $3.57126 \mathrm{E}-17$ & \\
$\mathrm{P}(\mathrm{T}<=\mathrm{t})$ two-tail & 1.692360309 & \\
$\mathrm{Z}$ Critical two-tail & $7.14253 \mathrm{E}-17$ & \\
\hline
\end{tabular}

From the table above, it is evident that there was a weak positive correlation on the pre and post crisis Influence of Standard \& Poors index and NSE 20 Share index. This is in disagreement with the works of Komo and Ngugi (2013), who found that there was high financial contagion between the developed world and the performance of NSE 20 Share index. Z statistical was greater than $\mathrm{z}$ critical and this led to the statistical value appearing in the critical region. This meant that the Influence of the two indices was statistically significant at 0.05 level of significance. This was confirmed by the $\mathrm{P}$ value which was less than 0.05. Finally, on the inferential statistics in respect to financial contagion, a relationship amongst the three indices, FTSE 100, Standard \& Poors and NSE 20 Share Index was established. Table 4.9 captures the correlation coefficients of that relationship. Pearson correlation between NSE 20 and FTSE 100 was 0.425, NSE 20 and Standard \& Poors 0.272 while that of FTSE 100 and Standard \& Poors -0.415 . The p 
values attributed to the above observations were $0.007,0.063$ and 0.008 respectively. The above observations are not in agreement with the work Komo and Ngugi (2013).

\section{Table 9}

Correlation Coefficients on the Influence of Financial Contagion on Performance of NSE 20 Share Index

\begin{tabular}{llccc}
\hline & & NSE 20 & FTSE 100 & \multicolumn{1}{c}{ STD \& POORS } \\
\hline \multirow{3}{*}{ Pearson Correlation } & NSE 20 & 1.000 & -.425 & .272 \\
& FTSE 100 & -.425 & 1.000 & -.415 \\
& STD \& POORS & .272 & -.415 & 1.000 \\
Sig. (1-tailed) & NSE 20 &. & .007 & .063 \\
& FTSE 100 & .007 &. & .008 \\
$\mathrm{~N}$ & STD \& POORS & .063 & .008 &. \\
& NSE 20 & 33 & 33 & 33 \\
& FTSE 100 & 33 & 33 & 33 \\
\hline
\end{tabular}

The above results show weak negative correlations between the Influence of NSE 20 Share Index and FTSE 100, and FTSE 100 and Standard \& Poors Index with statistically significant P values. This shows that the movements of these indices during the pre and post crisis periods were statistically significant. The correlation between NSE 20 Share Index and Standard \& Poors was weak positive correlation albeit not statistically significant at 0.05 Level of significance. This could imply that the NSE 20 Share index and Standard and Poor's were moving in the same direction. The model regression summary showed an R value of 0.438 , $R$ square of 0.19 , F Statistical of 3.552 and significance value of 0.041 . This is captured on Tables 10 and 11.

\section{Table 10}

Model Summary on the Influence of Financial Contagion on Performance of NSE 20 Share Index

\begin{tabular}{llllllllll}
\hline Model & $\mathrm{R}$ & $\mathrm{R} \mathrm{Sqr}$ & $\begin{array}{l}\text { Adjusted } \\
\text { Square }\end{array}$ & $\begin{array}{c}\text { R Std. Error } \\
\text { Estim }\end{array}$ & $\begin{array}{l}\text { of Change Statistics } \\
\text { R Square F Change } \\
\text { Chang }\end{array}$ & df1 & df2 & Sig. F Change \\
\hline 1 & $.438^{\mathrm{a}}$ & .191 & .138 & 925.25 & .191 & 3.552 & 2 & 30 & .041 \\
\hline
\end{tabular}

From the above, it is worth noting that the relationship among the three indices was statistically significant at 0.05 level of significance. A multiple regression model was established from the relationship among the three indices. The multiple regression model was as follows:

$\mathrm{y}=6734.17-0.603$ FTSE $100+0.706$ Standard and Poors

This relationship confirms the line graph in Fig. 10 above and the correlation matrix shown in Table 10. This is shown on Table 11.

\section{Table 11}

Regression Coefficients on the Influence of Financial Contagion on Performance of NSE 20 Share Index

\begin{tabular}{|c|c|c|c|c|c|c|c|c|}
\hline \multirow{2}{*}{\multicolumn{2}{|c|}{ Model }} & \multicolumn{2}{|c|}{$\begin{array}{l}\text { Unstandardized } \\
\text { Coefficients }\end{array}$} & $\begin{array}{l}\text { Standardized } \\
\text { Coefficients }\end{array}$ & \multirow[t]{2}{*}{$\mathrm{T}$} & \multirow[t]{2}{*}{ Sig. } & \multicolumn{2}{|c|}{$95.0 \%$ Confidence Interval for B } \\
\hline & & $\mathrm{B}$ & Std. Error & Beta & & & Lower Bound & Upper Bound \\
\hline \multirow{3}{*}{1} & (Constant) & 6734.17 & 2688.47 & & 2.505 & .018 & 1243.588 & 12224.759 \\
\hline & FTSE 100 & -.603 & .289 & -.377 & -2.087 & .045 & -1.193 & -.013 \\
\hline & STD \& POORS & .706 & 1.101 & .116 & .641 & .526 & -1.543 & 2.955 \\
\hline
\end{tabular}

\section{Discussion}

Inferential statistics on the primary data analysis of the Influence of Financial Contagion on the Performance of NSE 20 share index was positive at 0.672 and statistically significant with a $P$ value of 0.03 . The above observations were in respect to primary data. The correlation between Financial Contagion and NASI, 0.427; this was a weak positive correlation. Results on the same table showed a significance of 
0.056. This implied that the results were not statistically significant. The primary data correlation Influence of Financial Contagion on the Performance of FTSE NSE 15 index was a strong positive at 0.595 with a P value of 0.01 . This was below the threshold of 0.05 implying that the observations were statistically significant. The correlation between Financial Contagion on the Performance of FTSE NSE 25 Index as captured by the primary data was a weak negative of -0.141 and a $P$ value of 0.308 , this being statistically insignificant at 0.05 level of significance. On secondary data analysis on the relationship this analysis, data was split into pre crisis period, post crisis period and a combination of the pre and post crisis period. The correlation between FTSE 100 and NSE 20 Share Index stood at 0.763 . The $z$ statistical was at -14.532 , $\mathrm{z}$ critical at 2.1 and $\mathrm{P}$ value at 2.118893E-11. At 0.05 level of significance, the results were statistically significant. The Influence of the Standard and Poor's Index and the performance of NSE 20 Share Index. There were a total of 15 observations with $\mathrm{z}$ statistical of $10.86, \mathrm{Z}$ critical of 2.144 an P value of $3.328 \mathrm{E}-$ 12. These observations showed that the statistical value of $z$ was inside the critical region and therefore were statistically significant. The researcher studied the post crisis period Influence of FTSE 100 and NSE 20 Share index, Standard and Poor's Index and NSE 20 Share Index. On the Influence of Standard \& Poors and NSE 20 share index, the correlation between the two indices was 0.847, z statistical was 20.72016097, $\mathrm{z}$ critical was 2.10092204 , and the $\mathrm{P}$ value was $5.22553 \mathrm{E}-14$. These results were statistically significant at 95\% degree of confidence. The post crisis Influence of FTSE 100 and NSE 20 Share Index. The correlation between the two indices stood at $-0.57, \mathrm{Z}$ statistical was $3.94383631, \mathrm{Z}$ critical was 2.042272456 and the $\mathrm{P}$ value was 0.00044547 making the Influence of the two to be statistically significant. The final aspect hypothesis testing was done on the pre and post crisis Influence of financial contagion and the performance of NSE indices. The pre and post crisis Influence of the FTSE 100 and NSE 20 Share Index found that the correlation between the two variables stood at -0.4261121 , z statistical was 8.463637222 , z critical was 2.006646805 and the $\mathrm{P}$ value was $2.37289 \mathrm{E}-11$. This was statistically significant at 0.05 level of significance. The pre and post crisis Influence of Standard and poor's index and NSE 20 Share Index found that the correlation between these two variables stood at 0.27 , z statistical was 15.70199838 , $\mathrm{z}$ critical was 2.034515297 and $\mathrm{P}$ value was 7.14253E-17 which was statistically significant. Finally, on the inferential statistics in respect to financial contagion, a relationship amongst the three indices, FTSE 100, Standard \& Poors and NSE 20 Share Index was established. The Pearson correlation between NSE 20 and FTSE 100 was -0.425 , NSE 20 and Standard \& Poors 0.272 while that of FTSE 100 and Standard \& Poors -0.415. The $\mathrm{p}$ values attributed to the above observations were 0.007 and 0.063 , which were all statistically significant. The model multiple regression summary showed an $\mathrm{R}$ value of 0.438 , R square of $0.19, \mathrm{~F}$ Statistical of 3.552 and significance value of 0.041 . From the above, it is worth noting that the relationship among the three indices was statistically significant at 0.05 level of significance. From the above, the null hypothesis that there is not significant Influence of Herding Effect on the Performance of NSE indices was therefore rejected at 0.05 level of significance.

\section{Conclusions}

It can be concluded that in respect to the objective of financial contagion, there was a statistically significant presence of financial contagion both from the secondary data analysis and the views collected the from the market informants. This could imply that our exchange performance is highly contagious of the happenings surrounding it, which could be local or foreign based events. Our exchange is highly affected by the economic booms or downs, exchange rate fluctuations and even global events like recession. On this objective, market participants gave the impression through their responses that the indices that were highly contagious with the external world were the NSE20 Share and FTSE NSE 15 index while the contagion of the NASI and FTSE NSE 25 indices were not statistically significant in respect to financial contagion. This could be because the best firms are found in the NSE 20 share index and the largest 15 firms by market value are found on the FTSE NSE 15 index-by this, they are also among the best firms. In respect to the objective of Securities Price Volatility, the market informants gave the impression that the 25 most liquid companies listed in the NSE are significantly affected by the Securities 
Price Volatility trends in the index. This is due to the fact that being the most liquid firms, price fluctuations really affect the index performance. This however, contradicts their views on the case of financial contagion above.

\section{References}

Aduda, J., Odera, E. O., \& Onwonga, M. (2012). The behaviour and financial performance of individual investors in the trading shares of companies listed at the Nairobi stock exchange, Kenya. Journal of Finance and Investment Analysis, 1(3), 33-60.

Ahmed, M. M. (2010). Global Financial Crisis Discussion Series, Paper 19: Sudan Phase 2. Overseas Development Institute, London, UK.

Blair, B. J., Poon, S. H., \& Taylor, S. J. (2000). Modelling S\&P 100 volatility: The information content of stock returns, Forthcoming. Handbook of Quantitative Finance and Risk Management, 1333-1344

Dungey, M., Fry, R., González-Hermosillo, B., \& Martin, V. L. (2007). Contagion in global equity markets in 1998: The effects of the Russian and LTCM crises. North American Journal of Economics and Finance, 18(2), 155-174. https://doi.org/10.1016/j.najef.2007.05.003

Dungey, M., \& Gajurel, D. (2015). Contagion and banking crisis - International evidence for 2007 - 2009 q. Journal of Banking Finance, 60, 271-283.

Fabozzi, F. J., \& Peterson, P. P. (2003). Financial Management and Analysis. (W. Finance, Ed.) (2nd ed.). New Jersey: The Frank J. Fabozzi Series.

Hájek, J. (2007). CZECH CA PI TAL MAR KET WEAK-FORM EF FICIENCY, SE LEC TED IS SUES, (Mic), 303-318.

Hmida, M. (2014a). Financial contagion crisis effect of subprime on G7: Evidence through the adjusted correlation test and non-linear Error Correction Models ( ECM ). 2(5), 180-187.

Hmida, M. (2014b). Financial contagion crisis effect of subprime on G7 : Evidence through the adjusted correlation test and non-linear Error Correction Models ( ECM ). Financial Contagion Crisis Effect of Subprime on G7: Evidence through the Adjusted Correlation Test and Non-Linear Error Correction Models (ECM), 2(5), 180-187.

Islam, R. (2014). Comparing financial contagion and volatility spill over and structural break within major Asian economies pre and post global recession to that of Asian crisis. Journal of Applied Business \& Economics, 16(4), 92-112.

Kadilli, A. (2014). Working Paper Series Return Predictability in International Financial Markets and the Role of Investor Sentiment Anjeza Kadilli, (August).

Komo, L., \& Ngugi, I. (2013). Behaviour of bank share prices and their impact on national stock market indices: Comparing countries at different levels of economic development during recessionary and nonrecessionary periods. International Journal of Economics and Finance, 5(3), 49-61.

Ozkan, F. G., \& Unsal, D. F. (2012). Global Financial Crisis, Financial Contagion, and Emerging Markets. IMF Working Papers, 12(293), 1. https://doi.org/10.5089/9781475551167.001

Pilinkus, D. (2010). Macroeconomic indicators and their impact on stock market performance in the short and long run: The case of the baltic states. Technological and Economic Development of Economy, 16(2), 291-304.

Shen, Y. (2011). Can Stock Indices Be Made Better At Predicting Financial Contagion - A Network Model, (September), 1-23.

Sornette, D. (2003). Critical market crashes. Physics Reports, 378(1), 1-98.

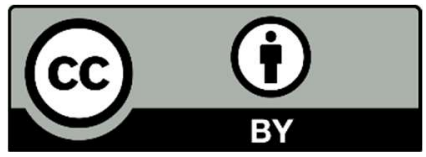

(C) 2020 by the authors; licensee Growing Science, Canada. This is an open access article distributed under the terms and conditions of the Creative Commons Attribution (CC-BY) license (http://creativecommons.org/licenses/by/4.0/). 